Maria Alekseeva

Стручни рад

alekseeva@rgub.ru

Ksenia Kosachkova

UDK 007:027.54]:004(470)

616.98:578.834(100)"2020"

kosachkova@rgub.ru

https://doi.org/10.18485/bibliotekar.2020.62.2.4

Russian State Library for Young Adults

Moscow, Russia

\title{
RUSSIAN LIBRARIES FOR YOUNG ADULTS: PROPER RESPONSE TO THE CHALLENGES OF THE COVID-19 CRISIS
}

\begin{abstract}
Due to the COVID-19 pandemic, all public libraries in Russia had to temporally stop providing services and conducting events at their physical spaces from mid-March up to mid-June 2020. However, the work of library specialists did not stop at that moment, it switched quickly to the online mode. Libraries used this extraordinary situation for developing new types and forms of their activities and services.

The Russian State Library for Young Adults (RSLYA) ${ }^{1}$ is the largest library dedicated to young adults in Russia and one of the eight Russian federal-level libraries. Since the RSLYA acts as an information and consulting centre for the Russian young adult library network, as well as other libraries serving young people, it has been monitoring, aggregating, and sharing information on library activities and services during the whole period of the lockdown.

The article highlights the best and successful practices of online and digital services for young library users. We are convinced that most of the proposed cases can be adapted and implemented in libraries working with young people in different countries.
\end{abstract}

Keywords: libraries for young adults, library services for young users, online library services, Russian libraries, COVID-19 crisis.

1 Russian State Library for Young Adults, https://rgub.ru/en/ (accessed 7. 9. 2020). 
Nowadays, the effectiveness and relevance of libraries largely depend on how well they are involved in the process of digitization. This is especially noticeable in working with young people since they are quite deeply immersed in new information technologies and more than other age groups interested in providing themselves with a comfortable digital environment and obtaining library services quickly in digital mode. The importance of coping with the new reality was once again highlighted by the COVID-19 crisis and restrictive measures for face-to-face user services. How can today's libraries respond to current challenges? What projects and events they implement in digital mode? How do libraries adapt traditional forms of activities to the virtual environment?

\section{Literature projects, reading challenges, and online book clubs}

It is important to find a positive side of any situation. The lockdown was a good chance to dive into the world of literature in a relaxed atmosphere. Moreover, the activities of the libraries encouraged users to do so. For example, the Book Challenge ${ }^{2}$ was launched by the Svetlov Central Library for Young Adults in Moscow in January 2020. Its participants have to challenge themselves and read 20 books by the end of the year based on a special list. The list includes comics, award-winning books, campus novels, favorite books of your family, books taken from friends or library, etc. In other words, a wide range that allows participants to engage in different topics, genres, and senses of literature. A reader has to make a review of a book in text or video format and post it on social networks with the hashtag \#svetlovkachallenge. For those who will complete the task before others, the library has prepared prizes from its partners, including gift certificates for books, museum tickets, online access to lectures and workshops, etc.

The School of Volunteer Initiatives "Our Business", based at the Makhaev Murmansk Regional Children's and Youth Library, offered an interesting option for schoolchildren and students during the lockdown. Organizers launched the \#ReadinQuarantine Volunteer Project which encouraged young people to make a short promo video about their favorite book or take a selfie with this book adding a brief description of it. Library volunteers posted reviews of the book "Diary of a Wimpy Kid" by Jeff Kinney, an American children's writer, game inventor, and cartoonist, and of the book "A HORMONic body. How to

2 Book Challenge Project, https://www.svetlovka.ru/events/other/2020-god-20-knig/ (accessed 7. 9. 2020). 
deal with metabolic disorders and chronic fatigue" by the Russian doctor and blogger Marina Berkovskaya. Volunteers of the Murmansk Children and Youth Library are actively implementing other useful projects. For example, in April volunteer Ekaterina Kozyreva began to lead the Evening Story Project. In the evenings, she reads online to children and their parents the fairytales of famous children's writers. You can find all the activities of the library volunteers in the \#НАШЕgело group ${ }^{3}$ on VKontakte social media.

The National Library of the Udmurt Republic offers its users online readings. The meetings are organized within the framework of the Reading Roles Book Club aimed both at high school students and first-year university students. The club's programme includes several blocks: the dramatisation of parts from a book; presentation of poems and prose or parts of them with subsequent analysis; imitation of classical literary "duels"; literary quizzes and meetings with specialists from the literary sphere. Usually, the meetings are held at the library, but due to the lockdown, they moved online.

\section{Workshops, online meetings, marathons, and even games}

You can get together and arrange creative performances in a cozy environment even in a remote mode. The Centralized Library System of the Eastern Administrative District of Moscow has organized creative online meetings as part of the Link Network Project across Russia. Each online meeting is mostly dedicated to one direction of creativity. From 3 to 12 people take part in it, sharing their best practices with each other, discussing them together, and communicating on any topic. The online meetings also have its own presenter who moderates the whole process: introduces participants of the meeting, initiates various discussions, keeps an eye on comments on the video, and answers questions from the audience. There have been held online meetings with poets, storytellers, and musicians. Colleagues from other regions also joined the action, in particular the libraries of St. Petersburg, the Vologda region, and the Republic of Buryatia. All meetings are broadcast live on social media. You can view the recordings in the official group of the project ${ }^{4}$ on VKontakte social media.

\footnotetext{
School of Volunteer Initiatives "Our Business", https://vk.com/club185716010 (accessed 7. 9. 2020). Link Network Project, https://vk.com/vssilke (accessed 7. 9. 2020).
} 
Workshops are good forms of communication because they are versatile and not bound to a particular place. The libraries have held many workshops online. Concerning young people's interest in graphic novels, the Belgorod State Scientific Library has arranged an online workshop on creating comics.

Innovative creativity built in the form of "learning through doing" is one of the most popular types of activity among young people today. Since the end of March, the Central Library of Muravlenko City (Yamalo-Nenets Autonomous Okrug) has been launching training videos on 3D modeling using the Blender, free graphic software toolset. The library specialist gives step-bystep instructions for the process of building a pre-selected 3D object, such as a rocket, a chair, an order, or even an entire room. In addition, the participants of the workshop, who send their projects to the specialist, have a chance to print them out to a 3D printer. Training sessions are held within the framework of the Naukograd Project - the laboratory of innovative creativity (FabLab) that has been operating in the Central Library of Muravlenko since 2017.

Various contests and marathons have been actively held in libraries. Participants of the Elm Literary Community based at the Shakhovsky Astrakhan Library for Young Adults has launched a creative marathon called "FastArt". According to its rules, every two days a new topic is set in the official community group ${ }^{5}$ on which you had to offer your work - it can be a poem, prose, photo, or drawing. Some of the topics are: "Such a strange spring", "All the colors of the world", "Animal theme", "Fairy tale story", "Conversation with...", and "Feelings are the main thing".

From February 1 to April 20, 2020, the Chelyabinsk Regional Library for Young Adults offered its users to train their writing skills by organizing the Regional Youth Creative Contest of Fanfics "Fantastic Duet". According to its terms, young people had to think about the development of the books of famous Sci-Fi writers of the XX century, celebrating 100th birth anniversary in 2020 - Ray Bradbury, Isaac Asimov, and Arkady Strugatsky. Young people were very enthusiastic about this proposal. They took various books as a basis, among them: "There Will Come Soft Rains" by Ray Bradbury, "Profession" by Isaac Asimov, and "Stalker" by Arkady and Boris Strugatsky.

Games are another good option to brighten up your time at home. The Library of Friends of the Centralized Library System of the Moscow district of

Elm Literary Community, https://vk.com/club151932379 (accessed 7. 9. 2020).

6 Regional Youth Creative Contest of Fanfics “Fantastic Duet”, http://mbi74.ru/novosti-i-sobytiya/3285-itogi-konkursa-fanfikov (accessed 7. 9. 2020). 
St. Petersburg invited users of Vkontakte social media to participate in a game to create a library story. According to its rules, librarians post part of the story, and the further development of the plot is determined by readers by selecting one of the suggested items. Participants of the game can also share their ideas about the story and actions of its heroes. You can follow the process of creating the library story in the official group of the library ${ }^{7}$ on Vkontakte social media.

\section{Multimedia projects}

The Yekaterinburg Library Centre ${ }^{8}$ implements creative online projects. Many of them appeared recently - during the lockdown. For instance, an interactive chronological long read Books for 23 Years dedicated to the 23rd anniversary of the centre. This digital project consists of three parts covering the periods 1997-2003, 2004-2009, and 2010-2020. Each part offers a reader to see the significant changes in various aspects of life, in particular in sports, fashion, literature, and pop culture, which determined the nature of the marked time and influenced the value perception, habits, and tastes of people. Among these events, there are many things that are close and easy to understand primarily by the younger generation: all sorts of internet memes, challenges, games, popular music videos, etc. Each long read is accompanied by a selection of the most popular books published in a particular year.

Another unusual online project of the Yekaterinburg Library Centre is the interactive project Black-and-White. It shows the positive (white) and negative (black) sides of writers and poets that they have observed in themselves on the basis of their personal diary entries. The first issue is dedicated to Leo Tolstoy.

In addition to these digital projects, the centre also provides an interactive map of places for reading fans called Yekaterinbook, a seasonal book calendar, and podcast series Wicker Languages.

For the 75th anniversary of the Victory in the Great Patriotic War, libraries have prepared many projects aimed at the younger generation. For example, the Republican Children's and Youth Library of the Republic of Buryatia, together with the Resource Center for Patriotic Education, Tourism and Sports of the Republic of Buryatia, has prepared a multimedia project of local history Four

Library of Friends, https://vk.com/biblioteka2 (accessed 7. 9. 2020).

8 Yekaterinburg Library Centre, https://xn----9sbaqbobjpwdg6avg5dn7e.xn--80acgfbsl1azdqr. xn--plai/about.php?lang=eng (accessed 7. 9. 2020). 
Years - Four Lessons ${ }^{9}$. It consists of four video lectures, each of which is dedicated to one significant event of the Great Patriotic War and the participation of the natives of Eastern Siberia in it. Methodologists of the Resource Center, specialists of the Children's and Youth Library, and the head of the Search Volunteer Organisation "Lynx" were among the speakers of the project.

The Far Eastern State Scientific Library has launched a digital local history resource called Natural Reserves Online ${ }^{10}$ designed to increase environmental education among young people. In 2019, this project became one of the winners of the grant competition of the Rosmolodezh Federal Agency for Youth Affairs. Natural Reserves Online is an ecological and educational resource that collects information on 13 specially protected natural territories in the Khabarovsk Krai. In addition to the address and contact database, you can find detailed information with maps, infographics, and various photos and videos of flora and fauna. At the end of each article, there is a list of books and other resources on these protected areas, which can be found at the Far Eastern State Scientific Library. In addition, the website contains information on environmental protection, for example, on the correct distribution of waste, saving water, etc.

\section{Podcasts}

The rapid appearance of podcasts in Russian libraries attracts considerable attention. In April, the Krasnoyarsk Regional Library for Young Adults launched a series of podcasts, in which librarians and invited guests discuss current topics related to literature and art. Audio content comes out weekly on Mondays in the official group of the library on Vkontakte and Youtube ${ }^{11}$.

The Samara Regional Youth Library, with the help of podcasts, decided to expand the form of its another project - Book Talks - a discussion club, the meetings of which are usually held in offline mode.

The Youth Library of the Komi Republic has created its own podcast project called Salinger's Cheesecakes ${ }^{12}$. Here, young librarians talk about books and

9 Multimedia Project "Four Years - Four Lessons", https://baikalib.ru/projects/2087/ (accessed 7. 9. 2020).

10 Digital resource "Natural Reserves Online", http://zapovedniki-online.ru/ (accessed 7. 9. 2020).

11 Podcast project of the Krasnoyarsk Regional Library for Young Adults, https://www.youtube. com/playlist?list=PLNTCJ15kV20B6dy0h5GFKYAeuaONMDHn5 (accessed 7. 9. 2020).

12 Salinger's Cheesecakes Podcast Project, https://www.youtube.com/playlist?list=PLSCgPKkjxYK n693h5YkFzpid3pO25H3sM (accessed 7. 9. 2020). 
literature. In the future, they plan to expand the range of topics, but the emphasis remains unchanged - promoting reading among young people.

The Youth Library of the Komi Republic has implemented another literature podcast project called Book Talks ${ }^{13}$ on the Discord messenger platform, which is usually used for voice broadcasts and conferences. On this audio server, anyone could listen to librarians' stories about literature in real time and take part in various discussions with the help of a text chat, to which you can additionally add links, pictures, and files up to $8 \mathrm{MB}$.

\section{Library campaigns}

Surprisingly, the lockdown has become a time for large-scale library campaigns. From March 28 to April 11,2020, the National Educational Campaign Digital Dictation ${ }^{14}$ was conducted in Russia. It is the largest digital literacy testing organized by the Regional Public Centre for Internet Technologies, the Microsoft Corporation, and the All-Russia People's Front Public Movement. This year, libraries around the country joined the campaign for the first time. The Russian State Library for Young Adults has become its informational partner and coordinator of its implementation in the public libraries in the whole country. The Digital Dictation is online testing designed for different age groups: children (7-13 years old), teens (14-17 years old), and adults (18 years and older), and divided into 4 content blocks - the basics of digital consumption (various devices and knowledge of basic programs and applications), digital competencies (work with the internet, social networks, online stores, and other online services), digital security (including protection of personal data and devices), and new technologies (AI, IoT, blockchain). There have been 115 libraries from 38 regions of Russia taking part in this campaign. Initially, the organizers offered the libraries various forms of participation like offline locations and sample scenarios for holding events at them. However, due to the COVID-19 pandemic in the country and in the world, libraries were not able to become offline locations but actively joined the information campaign by posting materials about the Digital Dictation on their electronic resources and social networks. Besides, 42 libraries have conducted closed corporate testing for their staff members.

13 Book Talks Podcast Project, https://discord.com/invite/489RcPQ (accessed 07.09.2020).

14 National Educational Campaign Digital Dictation, https://digitaldictation.ru/ (accessed 7. 9. 2020). 
In March 2020, the Smart Library Hackathon ${ }^{15}$ took place on the premises of the Belinsky Sverdlovsk Regional Universal Scientific Library with the participation of Moscow, St. Petersburg, and Chelyabinsk. Besides the Library, its main organizers were Cisco Systems, Channel One Russia, and the ShariX Platform. The main goal of the two-day forum was to develop various IT solutions for seven libraries of the Sverdlovsk region to turn them into modern, accessible, and attractive places for young people. Technically advanced high school and university students from the cities of Yekaterinburg, Kamensk-Uralsky, Novouralsk, Pervouralsk, and Serov were invited to implement the project. The competition had three categories: "Integrated Solution", "Infrastructure Solution" and "Digital Services". Seven teams worked on creating the product, each of them included one library expert, one technical expert, and four young participants. Beforehand, young creators spent more than two months visiting Sverdlovsk libraries, learning more about their environment, resources, and services. In addition, they took part in workshops on IoT, VR and AR, visualization and design, digital platforms, and business modeling at various venues in Yekaterinburg. As a result of the hackathon, a team from the city of Serov won the competition with a mobile app for libraries. IT experts also have noted the products of other teams such as prototypes of a chatbot, an integrated website (with the option to embed an online quest), navigation based on IoT technology, and two products of VR technologies. These and other concepts noted by IT experts will soon find practical application in the libraries of the Sverdlovsk region.

In April 2020, the Mayakovsky Kaliningrad Regional Youth Library implemented unusual online reading sessions called Peoples of All Countries, Unite! The library called via Instagram young people from all over the world to read their favorite poetry in their native language on camera. Young people from 15 countries, including China, Poland, Latvia, and Syria, responded to the call. ${ }^{16}$

15 Smart Library Hackathon, https://rgub.ru/schedule/online/item.php?new_id=10264 (accessed 7. 9. 2020).

16 Online reading sessions "Peoples of all countries, unite!", https://www.youtube.com/watch?time_ continue $=61 \& \mathrm{v}=5 \mathrm{~h} s \_\mathrm{vOHN} 8 \mathrm{BM} \&$ feature $=$ emb_logo $($ accessed 7. 9. 2020). 


\section{Conclusion}

All the cases presented above give us the confidence to conclude that libraries and librarians in Russia perceived the current situation as a new challenge, a chance to show their knowledge and competencies, to improve their skills in using new technologies by increasing digital content and interacting with their users in an online mode. It is likely that some people did not know about all the services the library is ready to offer, but now that they have noticed and appreciated them during the lockdown, they will continue to use it in the future.

This article highlights the most successful and interesting cases of online and digital services for young users implemented by Russian libraries during the lockdown. However, it is essential considering that not all libraries have found themselves in equal conditions. Those who had actively developed the digital component of their activities and services before the COVID-19 crisis, when faced with new circumstances, were at an advantage - it was easier for them to move to a new operating mode. Other libraries had to make efforts to master new knowledge and competencies in the shortest possible time in order to be able to provide their services online and stay tuned with their users.

Thus, the new reality of the lockdown worldwide has made the necessity of digital knowledge, skills, and competencies for librarians more obvious than ever. It has indicated a particular relevance of the process of digitization in libraries, which implies training librarians both for advising in digital literacy and for forming libraries' digital environment.

In this case, we can assume that various educational and training programmes on new technologies, digital literacy, and online communication designed specifically for librarians are in the highest demand. They help library specialists to acquire skills for working with new digital resources and technologies, to widen their understanding of a variety of instruments and ways for raising the quality and efficiency in serving users, especially the young ones. 


\section{References:}

1. Book Challenge Project, https://www.svetlovka.ru/events/other/2020-god-20-knig/ (accessed 7. 9. 2020).

2. Digital resource "Natural Reserves Online”, http://zapovedniki-online.ru/ (accessed 7. 9. 2020).

3. Elm Literary Community, https://vk.com/club151932379 (accessed 7. 9. 2020).

4. Library of Friends, https://vk.com/biblioteka2 (accessed 7. 9. 2020).

5. Link Network Project, https://vk.com/vssilke (accessed 7. 9. 2020).

6. Multimedia Project "Four Years - Four Lessons", https://baikalib.ru/projects/2087/ (accessed 7. 9. 2020).

7. Online reading sessions "Peoples of all countries, unite!", https://www.youtube. com/watch?time_continue $=61 \& \mathrm{v}=5$ hs_vOHN8BM $\&$ feature $=$ emb_logo (accessed 7. 9. 2020).

8. Regional Youth Creative Contest of Fanfics "Fantastic Duet", http://mbi74.ru/novosti-i-sobytiya/3285-itogi-konkursa-fanfikov (accessed 7. 9. 2020).

9. Russian State Library for Young Adults, https://rgub.ru/en/ (accessed 7. 9. 2020).

10. School of Volunteer Initiatives “Our Business", https://vk.com/club185716010 (accessed 7. 9. 2020).

11. Smart Library Hackathon, https://rgub.ru/schedule/online/item.php?new_id=10264 (accessed 7. 9. 2020).

12. Yekaterinburg Library Centre, https://xn----9sbaqbobjpwdg6avg5dn7e.xn--80acgfbsllazdqr.xn--plai/about.php?lang=eng (accessed 7. 9. 2020). 


\title{
Марија Алексејева
}

alekseeva@rgub.ru

\author{
Ксенија Косачкова \\ kosachkova@rgub.ru \\ Руска државна библиотека за младе \\ Москва, Русија
}

\section{РУСКЕ БИБЛИОТЕКЕ ЗА МЛАДЕ: АДЕКВАТАН ОДГОВОР НА ИЗАЗОВЕ КРИЗЕ ИЗАЗВАНЕ КОВИДОМ-19}

Сажетак: Услед пандемије ковида-19, све јавне библиотеке у Русији морале су привремено, од средине марта до средине јуна 2020, да обуставе пружање услуга и организовање догађаја у својим просторијама. Међутим, рад библиотечких стручњака није се тог тренутка зауставио, већ се брзо пребацио на онлајн режим. Библиотеке су искористиле ову неуобичајену ситуацију да развију нове моделе и облике својих активности и услуга.

Руска државна библиотека за младе (РГБМ) највећа је библиотека посвећена младима у Русији и једна од осам руских библиотека на савезном нивоу. Будући да РГБМ делује као информативни и консултантски центар за руску библиотечку мрежу за младе, заједно са другим библиотекама за младе надгледала је, обједињавала и делила информације о библиотечким активностима и услугама током периода изолације.

У раду се истичу најбољи примери праксе онлајн и дигиталних услуга за младе кориснике библиотека. Уверени смо да се већина предложених примера може прилагодити и применити у библиотекама које раде са младима у различитим земљама.

Кључне речи: библиотеке за младе, библиотечке услуге за младе кориснике, онлајн библиотечке услуге, руске библиотеке, криза услед ковида-19.

Примљено: 8. септембра 2020.

Исправке: 9. октобра 2020.

Прихваћено: 30. октобра 2020. 